\title{
Review
}

\section{War for peace: Genealogies of a violent ideal in western and Islamic political thought}

\author{
Murad Idris \\ New York, Oxford, 2019, 352pp., ISBN 978-0190658014
}

Contemporary Political Theory (2021) 20, S45-S48. https://doi.org/10.1057/s41296020-00379-4; published online 21 January 2020

Shortly before the ringing of the New Year in 2020, US President Donald J. Trump reassured the public that he was a man of peace. Pro-Iranian demonstrators had surrounded the American embassy in Baghdad, burned the reception area, and placed militia flags on the roof before withdrawing. Did the President foresee going to war with Iran? 'No. I want to have peace. I like peace.' Shortly thereafter, President Trump authorized a drone strike on Iranian Major General Qassim Suleimani, the leader of the Quds Force of the Islamic Revolutionary Guard Corps. According to analysts, Trump's act was effectively an American declaration of war against Iran (Crowley, Hassan, \& Schmitt, 2020).

In his important and profound book, War for Peace: Genealogies of a Violent Ideal in Western and Islamic Thought, Murad Idris counsels his readers against being surprised whenever people say that they want peace while simultaneously planning to kill their enemies. A call for peace, Idris shows, is almost always accompanied by a call for war against those who threaten the peace. The Great Seal of the United States has an eagle carrying an olive branch in one talon and arrows in the other; I have assumed that the point was that America offered other countries a choice between war or peace. After reading Idris's book, however, I suspect that the olive branch necessitates the use of arrows, and the arrows are justified because of the olive branch. At any event, Idris challenges anyone who thinks they can strive for peace without perpetrating violence: 'the belief in peace as a basic desire and universal aspiration occludes how readily its invocations dehumanize enemies, sanitize violence, and silence dissent' (p. xiii).

How does Idris go about problematizing something as popular as peace? By performing a genealogy of the idea in Western political thought. Through a reading of canonical political philosophers such as Plato, Thomas Aquinas, Desiderius Erasmus, Alberico Gentili, Hugo Grotius, Thomas Hobbes, and Immanuel Kant, Idris identifies a pattern in how they frame the problem of peace. The idea of peace in Western political thought 'functions parasitically, provincially, and polemically'

(c) 2020 Springer Nature Limited. 1470-8914 Contemporary Political Theory Vol. 20, S1, S45-S48 
(p. 2; emphasis in original). It is parasitic in that it is often conjoined with other concepts - such as friendship, unity, justice, law, or order - that require military and police power to realize. It is provincial in that people often express their particular aspirations and fears when identifying a peaceful order. And it is polemical in that philosophers often speak of peace while identifying who must be fought in order to realize peace. Contrary to Carl Schmitt, who points to the hypocrisy of peace talk, Idris argues that violence infuses the concept of peace itself: 'Not only can peace be weaponized, but its idealization is, structurally and discursively, crafted as a weapon, with specific enemies in view, and honed against specific others' (p. 7; emphasis in original).

Idris opens the book with a discussion of how President George W. Bush invoked peace while unleashing the Global War on Terror, and President Barack Obama said 'peace is hard' while authorizing drone strikes himself (pp. xiv-xv). Idris shows that this juxtaposition between saying peace and doing violence has a long history in Western political thought, from Plato's differentiation between Greeks and barbarians, to Erasmus's distinction between the peaceful Christian and the warlike Turk, to Kant's contrast between settled peoples and the Arabian Bedouins. Idris also examines the writings of three Muslim thinkers - al-Farabi, Ibn Khaldun, and Sayyd Qutb - whose treatments of the concept of peace are just as problematic as their Western counterparts. 'By examining the morals, oppositions, schematizations that make peace into a desire and ideal across the history of political thought', the book aims 'to unmake the apparent purity of peace' (p. xx).

The book succeeds in its mission of problematizing the ideal of peace. Each chapter attends to the context, nuances, and specificities of the thinkers under consideration - including flagging how problematic it is to speak of 'Western' or 'Islamic' thinkers - while still driving home the point that the grammar of peace has a lacuna that must be filled by enemies of peace. The book is filled with surprising juxtapositions and fresh insights on famous and less familiar authors who write about peace.

Chapter 6, for instance, compares and contrasts two of the leading thinkers invoked in the Global War on Terror: Sayyd Qutb, the inspiration for the militant jihadist group al Qaeda, and Immanuel Kant, the leading philosopher of liberal modernity. While Kant and Qutb differ in important ways, Idris shows that their visions of peace both require a world order of nation-states, federations, and military or police action against whoever threatens the peace. 'Through the two plans' shared orientation, from internal political form to federation to global policing, perpetual peace is deferred, and wars are authorized in its name' (p. 312). This observation chastens Kantian cosmopolitans who might not recognize that their vision of global justice emerged from a particular historical context, requires the perpetual overcoming of enemies, and may lead to imperialism. Idris also shows that Qutb was, at least in his work during the 1950s, as concerned with worldly matters of territory and economy as he was with the eschatological 
questions more prominently featured in his late polemic Milestones (Euben, 1999). Idris leaves the reader with a sinking feeling in their stomach that there will be no good outcome to the Global War on Terror as long as both sides strive for a notion of perpetual peace 'limited to consensus, sameness, and uniformity' (p. 313).

So, if peace is a problem, then what is the alternative? In a few tantalizing pages (pp. 8-9, 318-322), Idris points to an alternate conception of peace that has modest aspirations and thus perpetrates less violence. This conception of peace valorizes the notion of a truce that does not settle political questions once and for all, is particular to a time and place, and that separates rather than reconciles contending positions. But fleshing out a positive notion of peace, Idris explains, would require another book (p. 318).

Perhaps I may offer a suggestion about how to go about constructing a more generous conception of peace. In this book, Idris argues that 'constitutive antagonisms' are at the heart of Western and Islamic thinking about peace (p. 1), and the book examines thinkers who confirm that suspicion. In future work, Idris might read political theorists who work in a more 'agonistic' vein. For agonistic thinkers, differences are an inevitable aspect of human life on a crowded planet. Rather than make a sharp distinction between friends and enemies, agonists appreciate opponents for bringing out the best in ourselves. Though people should defend their identities from attacks, agonists encourage people to wrestle with, rather than seek to destroy, other faiths and practices. Rather than take Kant as the paradigmatic liberal thinker, Idris could read John Stuart Mill, whose On Liberty gestures towards a world order that appreciates different ways of life (Misra, 2012). Or rather than Qutb, Idris could look at Tariq Ramadan, whose concept of the dar al-shahada ('abode of testimony') provides an alternative to Qutb's distinction between dar al-Islam ('abode of Islam') and dar al-harb ('abode of war') (Tampio, 2011).

In addition, the book's genealogical ambition - 'unmake the apparent purity of peace' - risks overlooking relatively successful examples of peace. Might Idris consider how the Umayyad dynasty in medieval Spain, even if idealized, could serve as a model for a new vision of a peaceful society (Menocal, 2003)? Or what about cities where people of different faiths find ways to coexist peacefully, even if militants often threaten the peace? One wonders what insights Idris would gain if he steps outside of Western or Islamic thought - do any other traditions fare better about negotiating the peace/war binary?

Idris's War for Peace accomplishes at least three things. It provides a fresh perspective on canonical authors in the Western and Islamic intellectual tradition, including authors who have rarely been brought into conversation with one another, such as Kant and Qutb. It prompts us to recognize the darker side of calls for peace in places such as Palestine, Baltimore, or Iran. And it provokes us to construct a less vindictive conception of peace.

(C) 2020 Springer Nature Limited. 1470-8914 Contemporary Political Theory Vol. 20, S1, S45-S48 


\section{References}

Crowley, M., Hassan, F., and Schmitt, E. (2020) U.S. strike in Iraq Kills Qassim Suleimani, Commander of Iranian Forces. The New York Times, 2 January.

Euben, R. L. (1999) Enemy in the mirror: Islamic fundamentalism and the limits of modern rationalism: A work of comparative political theory. Princeton, NJ: Princeton University Press.

Menocal, M. R. (2003) The ornament of the world: How Muslims, Jews and Christians created a culture of tolerance in medieval Spain (Reprint ed.). Boston: Back Bay Books.

Misra, S. (2012) Friend, not foe: Mill's liberal multiculturalism. European Journal of Political Theory, 11(3): 273-291.

Tampio, N. (2011) Constructing the space of testimony: Tariq Ramadan's Copernican revolution. Political Theory, 39(5): 600-629.

Publisher's Note Springer Nature remains neutral with regard to jurisdictional claims in published maps and institutional affiliations.

Nicholas Tampio

Fordham University, The Bronx, NY 10458, USA tampio@fordham.edu 